\title{
Off-label Use in Germany - A Current Appraisal of Gynaecologic University DePARTMENTS
}

\author{
N. Ditsch ${ }^{1}$, C. Kümper ${ }^{2}$, M. Summerer-Moustaki ${ }^{4}$, S. Rückert ${ }^{1}$, B. Toth ${ }^{3}$, M. Lenhard ${ }^{1}$, M. A. Strauss ${ }^{2}$ \\ ${ }^{1}$ Department of Obstetrics and Gynaecology, Ludwig-Maximilians-University Munich, Campus Grosshadern, Munich \\ ${ }^{2}$ Department of Obstetrics and Gynaecology, Christian-Albrechts- University, Kiel, \\ ${ }^{3}$ Department of Obstetrics and Gynaecology, Karl-Ruprecht University, Heidelberg, \\ ${ }^{4}$ Praxis, Munich, Germany
}

\begin{abstract}
:
Objective: The off-label use, referring to the applicability of pharmaceutical drugs beyond the submitted and from the Federal Institute for Drugs and Medical Devices (BfArM, Bundesamt für Arzneimittel und Medizinprodukte) certified and approved administration, is the subject of controversial discussions. The application can be considered in case of severe illness - if no therapeutic alternatives are available - or it exists as a founded perspective for achieving therapeutic success. Methods: A latitudinal study for evaluating the application of off-label use supplements was performed at 43 German university and academic teaching hospitals. Five doctors at each hospital applied off-label pharmaceutical drugs and were called upon to share their personal experience to the application of those medications.

Results: 75 (35\%) questionnaires were returned out of $22(51 \%)$ medical centres with 215 contacted physicians. Off-label use was common for $65(91 \%)$ of the physicians. Only $9 \%$ of them obviate the application of off-label drugs. About a half of the medication is related to application in obstetrics $(54 \%)$ and in most cases on an every day basis. Uterotonics were the most commonly used off-label medications (34\%). The main part of information about off-label use is obtained from personal information of colleagues $(66 \%)$ and personal experience $(58 \%)$. 34\% of physicians think that off label use is risky. Interestingly, the view about off label use of medication varies considerably among physicians from various hospitals.

Conclusions: The application of off-label pharmaceutical drugs in Germany seems to be a well established practice. More than $90 \%$ of participators of our trial use at least one medication outside the administration.
\end{abstract}

This includes particularly prostaglandins, anti-hypertonic therapeutics and chemotherapeutics.

Key words: off-label use, Federal Institute for Drugs and Medical Devices (BfArM), Obstetrics and Gynaecology

Abbreviations: BfArM: Bundesamt für Arzneimittel und Medizinprodukte; FDA: Food and Drug Administration; SGB V: Strafgesetzbuch V, Penal Code; BSG: Bundessozialgericht, Social Federal Court; G-BA: Gemeinsamer Bundesausschuß, committee dealing with national issues; $\mathrm{BGH}$ : Bundesgerichtshof, Federal Court of Justice; BVG: Bundesverfassungsgericht, Federal Constitutional Court; AMG: Arzneimittelgesetz, German Medicines Law

\section{INTRODUCTION}

Just for oncologic indications a multitude of new, innovative and expensive drugs was licensed in the last 10 years. Increasingly, every new product development has to confront economic questions as hurdles. Regulatory aspects obtain an important part in this respect, while the limited indication of administration is based on studies after initial registration of the drugs [1].

The off-label use (Table 1), meaning the applicability of pharmaceutical drugs beyond the submitted and from the Federal Institute for Drugs and Medical Devices (BfArM, Bundesamt für Arzneimittel und Medizinprodukte; USA: FDA: Food and Drug Administration) certified and approved administration, is subject of controversial discussions in circles of various stakeholders such as health care payers, pharmaceutical industry, physicians, and patients.

Table 1. Off-label use.

\begin{tabular}{lll}
\hline $\begin{array}{l}\text { Legal consideration } \\
\text { (rechtl. Regelung) in Germany }\end{array}$ & Status of administration & Medical requirement \\
\hline $\begin{array}{l}\text { Pharmaceutical law not regulated; } \\
\text { permitted within therapeutic flexibility } \\
\text { of the physician, reimbursement in }\end{array}$ & $\begin{array}{l}\text { Permitted in different indication } \\
\text { (in Germany) }\end{array}$ & $\begin{array}{l}\text { Life-threatening diseases without } \\
\text { alternative therapeutic option and good } \\
\text { evidence for therapeutic success }\end{array}$ \\
\hline
\end{tabular}

(out of reference 1), SGBV (Sozialgesetzbuch 5): Social Security Code 5 
For prescription drugs, the BfArM approval process requires substantial evidence of efficacy and safety for specific clinical situations. Although off-label prescribing is legal and common, it is often done in the absence of adequate supporting data. Off-label use has not been formally evaluated, and evidence provided for one clinical situation may not apply to others. In order to increase awareness of off label use, public institutions are also becoming active in this area [2].

We hypothyse, that despite risks of litigation off-label use is common on German University and academic teaching hospitals.

\section{Material, Methods and Statistics}

From June 2006 until June 2007 a latitudinal study evaluating the application of off-label use supplements was performed at 43 German university and academic teaching hospitals - concentrating on the departments of Obstetrics and Gynaecology. Five physicians (respectively director, senior assistant medical director, youngest assistant medical director, senior and youngest intern) of each department were asked whether they applied off-label pharmaceutical drugs and about their personal opinion and information to the application of those medications.

The questions were divided among 3 main topics. The first included theoretical and practical experiences of the participant.

The second block was specific to the hospital use of off label medication for individual therapy and the differences among participating physicians.

The third part of the questionnaire referred to the individual physicians` background and opinion using off-label medications.

For the survey, qualitative data were entered into a SPSS database (version 16.0) and analyzed using SPSS software and open-ended questions were sorted and reported by response item.

\section{RESULTS}

215 physicians out of 43 German university and academic teaching hospitals (Department of Obstetrics and Gynaecology) were contacted twice, via letter. Seventy-five $(35 \%)$ questionnaires were returned from $22(51 \%)$ medical centres. This included the completed forms of 14 directors, 29 assistant medical directors and 28 interns. Four questionnaires were returned blank, either because no off label use was being performed in that hospital or due to lack of time for answering the questionnaire. Thus, for analysis of the single questions, 71 (33\%) questionnaires could be included.

The median professional experience of the participating physicians was 10 years (+/-SD 10,09, range 1 36 years).

Within the consulted physicians the professional experience ranged from 1 year to 36 years.

Off-label use was common for 65 physicians (91\%). Six physicians denied off-label use at their hospital. Therefore, answering the single questions was only possible for 65 of the physicians.

Answers related to off-label use at the individual hospital are summarized in Table 2.

Most of the directors thought using off-label is only common for directors, assistant medical directors and medical specialists $(10 / 13 ; 77 \%)$. However, many interns are convinced that off-label drugs are commonly used by young interns (11/26 interns; 42\%) themselves.

Most of the medications are ordered as hospitalmedication $(39 / 65,60 \%)$.

Rarely, further medications such as anticoagulants and immunotherapeutics were chosen. In obstetrics the most commonly used off label drugs were: Misoprostol, Nifedipin, Metformin.

In the case of off label medication use in the field of obstetrics, a main question was if the use is dependent or independent of gestational age of the patient.

Table 2. Answers related to off-label use at the individual hospital.

\begin{tabular}{|c|c|c|}
\hline Answers & Number of physicians (n) & Percentage $(\%)$ \\
\hline $\begin{array}{l}\text { Kind of physician, who administers } \\
\text { off-label drugs most commonly } \\
\text { (point of physicians view) }\end{array}$ & $\begin{array}{l}56 \text { (assistant medical directors) } \\
24 \text { (interns) }\end{array}$ & $\begin{array}{l}86 \\
66\end{array}$ \\
\hline $\begin{array}{l}\text { Frequency of using off-label } \\
\text { medicaments }\end{array}$ & $\begin{array}{l}31 \text { (daily) } \\
23 \text { (weekly) } \\
11 \text { (rare exception) }\end{array}$ & $\begin{array}{l}48 \\
35 \\
17\end{array}$ \\
\hline $\begin{array}{l}\text { Kind of procedure - going along with } \\
\text { off-label: } \\
\text {-product information } \\
\text {-technical literature } \\
\text {-educational advertising } \\
\text {-none }\end{array}$ & $\begin{array}{l}36 \\
55 \\
61\end{array}$ & $\begin{array}{l}55 \\
85 \\
94\end{array}$ \\
\hline $\begin{array}{l}\text { Most commonly used off-label } \\
\text { medicaments: } \\
\text {-Uterotonics } \\
\text {-Tocolytics } \\
\text {-Chemotherapeutics }\end{array}$ & $\begin{array}{l}22 \\
18 \\
15\end{array}$ & $\begin{array}{l}34 \\
28 \\
23\end{array}$ \\
\hline
\end{tabular}


Thirty-two physicians see a relation between off-label use and gestional age, especially for the use of Misoprostol (in case of incomplete abortion and/or inducing birth at gestional age of $37+0$ or above). In case of Nifedipin, the questioned physicians agreed in beginning with the off label use no earlier than the 24th week of gestation, where viability was guaranteed. In case of Misoprostol and Indomethacin results showed inconsistency for gestational weeks as specified in literature $[3,4]$.

\section{Awareness Regarding Legal Aspects}

Off-label use in Gynaecologic and Obstetric departments of university and teaching hospitals, according to physicians point of view, does not need the acceptance of the health insurance company (59/65, 91\%), costs are mostly accepted by health insurance company $(54 / 65,83 \%)$, is inside the insurance coverage $(64 / 65,98 \%)$, is not only allowed within treatment trials $(61 / 65,94 \%)$ and is not considered as a medical malpractice $(65 / 65,100 \%)$.

There is deep disagreement between the questioned physicians (37 vs. 29 and 32 vs. 34) as to whether offlabel use should only be permitted by medical specialist or only allowed with the consent of the hospital management.

Most physicians agree about the requirement of educational advertising and signed consent (60/65, $92 \%)$. The off-label use should be dependent on the indication $(55 / 65,85 \%)$.

\section{KNOWLEDGE}

A main part of information about off-label use in general is obtained from personal information of colleagues $(42 / 65,66 \%)$ and own experience $(38 / 65$, $58 \%$ ). Furthermore, information about off-label use is extracted from technical literature $(54 / 65,83 \%)$ and medical conventions $(41 / 65,63 \%)$. Half of the physicians get information from product information provided by the drug producer $(33 / 65,51 \%)$. Only a few physicians get their information through legal advice $(11 / 65,17 \%)$ and hardly anybody $(5 / 65,8 \%)$ obtains it via the internet.

\section{SubJeCtive SeLF-ASSESSMENT}

The personal estimation of the physicians could be classified as prohibited, risky or harmless. 22 (34\%) think that off-label use is a risky business, 28 (43\%) consider it as harmless - mainly young physicians $(65 \%)$. There were no significant differences between single groups (directors, assistant medical directors and interns). But in the group of interns there was a trend to harmlessness $(15 / 27 ; 56 \%)$. Nobody classified it as prohibited and $15(23 \%)$ out of the 65 physicians abstained from voting.

\section{Discussion}

Physicians' freedom to prescribe drugs off-label carries important advantages. It offers patients and physicians earlier access to potentially valuable med- ication and allows physicians to adopt new practices based on emerging evidence. It permits innovation in clinical practice, particularly when approved treatments have failed. Off-label use is frequently implemented to reduce costs (e.g. Misoprostol). But off-label use has potentially negative consequences, as well. It undercuts expectations that drug safety and efficacy have been fully evaluated. When newer, more expensive drugs are used off-label, it can lead to increase health care costs.

Off-label use is common practice in obstetrics and gynaecology. Our findings support these data. 91\% of the physicians use off-label drugs at regular intervals. Although in most cases medical specialist standard is required, using off-label drugs in Germany seems to be often standard for young interns, independent of their educational background. Interestingly enough although one of the employed physicians in one hospital referred to off-label use as a common practice for director, assistant medical director and interns, the director of the same hospital denied off-label use.

A data collection from Radley et al. showed an estimated 150 million off-label citations $(21 \%$ of overall use) among the sampled medications in 2001. Most off-label drug use $(73 \%)$ had little or no scientific support [5]. In contrast to this especially in neonatology almost all medicatons (up to 90\%) are used in off-label [1]. In order to solve this discrepancy a first step could be the improvement of the quality of product information [2] that currently presents deficient data concerning administration status [6].

Our data show that almost half of the physicians (43\%, 23\% abstained from voting) and particularly young physicians estimate off-label use as legal and safe. If a patient suffers from an off-label drug, the only person who can be made liable is the physician who prescribed the medication - independent of his standard of knowledge [7, 8]. In most cases personal liability insurance cover the physician. The questioned physicians are conscious of this business (98\%). Therapies are considered as co-insured when approved in medical science. Co-insured is the application of drugs, which are outside the permitted indication, if efficacy and harmlessness are documented in trials but enlargement of accreditation is not applied or already accorded [6]. Sole exception from holding liable the prescribing physician is the joint knowledge of a managing director of the health insurance company if the latter rendered services without legal foundation or against applicable enforceable law. In this situation (if statutory services are exceeded) the director of the health insurance company is liable for the costs.

Eighty-three percent of the physicians expect that the incurred costs for off-label drugs are payed by health insurance companies. But in principle, the SGB $\mathrm{V}$ (Strafgesetzbuch V, penal code) does not allow payment for off-label use by public health insurance companies. However, this principle does not imply that the substance cannot be successfully used or that the patient has no right to request and receive it. In a 2002 ruling [10] the BSG (Bundessozialgericht, the German federal social court) made it clear that there are exemptions from this rule and that patients do have the right to receive off-label drugs in case of: 
- severe and/or life threatening illness,

- no available alternative treatment; if there is an alternative therapy available or there exists a founded chance of success, off label use is often insufficient regardless of the educational background of the involved physician. For answering those questions the German cancer society (Deutsche Krebsgesellschaft) and medical associations are predestinated [8],

potential and/or evident treatment success (phase III trials) [11, 12]. The danger of insufficient drug safety in off-label use is considered minimal if the drug has passed the legally required safety tests [13], respectively existence of publications with consensus of expected success [14].

After newer opinions for admitting off-label use individual risk-benefit-analysis is of particular importance [15]. If therapeutic alternatives are missing, following steps are taken into consideration (Table 3) [11].

As a direct result of the 2002 BSG (Bundessozialgericht, Federal Social Court) ruling, an expert commission was founded at the BfArM (Bundesinstitut für Arzneitmittel und Medizinprodukte, Federal Institute for Pharmaceuticals and Medical Products) to solve the disputed off-label use conflict $[16,17]$. In case of missing comments of the expert commission for a special drug there is no absolute liability of the drug producer. There is a new adjudgement of the BVG (Bundesverfassungsgericht, Federal Constitutional Court), which is of overriding importance of the BSG: in a life-threatening situation and if alternatives are missing, off-label drugs could be used and costs refunded, even though there are weak references for efficacy [18].

In exceptional case a prescription of off-label drugs within the pharmaceutical product guideline is possible by debiting the health insurance company:

1. Positive recommendation of the expert commission for application of an off-label drug (the Federal Minister of Health and Social Security has established an expert commission to evaluate scientifically off-label use and provide advice on such practice [13]),

2. Acceptance of this off-label use as conventional use through pharmaceutical contractor,

3. Acceptance of the drug and the off-label indication in part $A$ of the drug guideline of the G-BA (Gemeinsamer Bundesausschuß, committee dealing with national issues) [14],

4. A licensed alternative does not exist.
In the board decision of the BSG (Bundessozialgericht, Federal Social Court) from 2006 for a physician it is possible not to decide by himself for off-label drug prescription, but to get a vote of credit from the accordant health insurance company. In case of decline it is feasible to expose a private prescription [19].

In some cases, only off-label use can guarantee the legally required treatment according to the newest scientific findings. Current jurisdiction has specified the conditions for off-label use [13].

In individual cases, it is quite possible that a physician is even enganged by civil law to use drugs off-label and in case of acting in opposition to it can be held liable because of failure to render assistance [20, 21].

The German BGH (Bundesgerichtshof, Federal Court of Justice) has commented on liability for medical malpractice in a new adjudgement from March 2007 in an individual treatment attempt [22]: The individual treatment attempt with a registration required but not yet licensed drug is not outlawed and is not yet an error in treatment.

The physician has to get active information (of his own accord) about off-label use [22]. Individual education of the patient is most important in using off-label drugs. The questioned physicians are in accordance with the existing law. Individual education should be carried out in detail information with advice for possible existence of unknown risks. The patient should sign the information form like patients in trials [22]. Ninety-two percent of the questioned physicians already follow these judical rules.

Half of the questioned physicians specified that they received their information from the industry. The industry may facilitate off-label use by exploiting areas of ambiguity where policy is permissive, undefined, or not enforced. Besides sponsorship of continuing medical education programs, a key promotional strategy is providing physicians with journal articles about off-label uses. This practice does educate physicians, but it is problematic because the trials reported are often of unclear quality, industry-sponsored, and placebo-controlled (rather than comparisons with approved therapies). In the USA the FDA's recently published draft guidelines address the distribution of journal articles by pharmaceutical sales representatives [23]. The guidelines suggest a more permissive attitude toward the promotion of off-label uses of drugs. Though they carry forward many provisions of the FDA Modernization Act, there are two glaring omissions. First, manufacturers need no longer limit their promotion of off-label uses to drugs and indications for which they

Table 3. Steps of the off-label-use if therapeutic alternatives are missing.

\begin{tabular}{|c|c|c|}
\hline Step & Severity of disease & Off-label use \\
\hline 1 & No severe disease & No off-label use \\
\hline 2 & Severe disease & $\begin{array}{l}\text { Off label use in well founded chance of } \\
\text { success }\end{array}$ \\
\hline 3 & Life-threatening disease & $\begin{array}{l}\text { Off-label use as well as in lower chance of } \\
\text { success }\end{array}$ \\
\hline
\end{tabular}

(out of reference 11) 
are working toward FDA evaluation; and second, there is no requirement for advance FDA review of the journal articles to be distributed [24].

In contrast to off-label use, an unlicensed-use means the application of imported verified therapeutics aside from clinical studies without admitted license or modified formulations of registered pharmaceutics $[25,26]$. In the USA the FDA prohibits the individual import of drugs which are not licensed [27].

Actually, 83\% of the physicians think that costs for off-label drugs are accepted by health insurance companies, but according to law, the pharmaceutical company is not engaged. In future, physicians will possibly not use off-label drugs because of the current major reimbursement problem of the health insurance company for the hospital. In Germany, current research into cost recovery showed that off-label use therapies are only financially viable until 500 Euro [28].

Currently, satisfying drug-legitimate solutions are not available [29]. In Germany, until now the off-label use is not regulated neither from the AMG (Arzneimittelgesetz, German Medicines Law), nor from Social Assistance Law. Our examination showed discordance of the physicians especially in questions of liability, reimbursement of costs and personal allowance of prescription - the physician has penal engagements and engagements by civil law (medical specialist) [12]. Within the asked persons 37\% think, that medical specialist standard is not necessary. This could implicate legal problems.

Physicians desire the autonomy to prescribe drugs that match individual patient needs regardless of label, but they face difficulties staying abreast of rapidly evolving evidence. More education to legal status in using off-label drugs (actually only 17\% engaged juristic advice) and cost coverage is necessary. The increasing consolidated medical findings and complexity of law as concentrated allocation-conflicts of the health care system will intensify the complexity of problems with the open questions of the off-label use in the future. To be a physician will require basic knowledge in social law and health care policy. A limitation of pure medicine won 't be possible, and would no longer be affordable in future [30].

As main point of this study it can be concluded, that off-label use is only permitted if there is no licensed alternative medication for an ascertained indication.

Using the example of Misoprostol (licensed drug for ulcer therapy) which however in obstetrics lacks a permitted off-label use the application is solely propagated through cost reduction, since although conventional prostaglandins are available, they are avoided due to high financial cost. For the most part this point seems to be the only motivation for using off-label medication. But it has to be constituted clearly, that Misoprostol use is not covered by off-label use only for cost-reduction. There does not exist an assumption of costs and legal coverage.

This and the missing absorption of costs through the health insurance company demonstrate a pulsating culmination point. Convergence of both sides is demanded for an optimal patient-maintenance.

\section{REFERENCES}

1. Choonara I, Conroy S: Unlicensed and off-label drug use in children. Drug Safety 2002; 25:1-5

2. Seyberth H.W.: Problems of Presription Drug Use in Children; Dtsch Arztebl Int 2009; 0023

3. Chong YS, Su LL, Arulkumaran S: Miosoprostol: a quarter century of use, abuse, and creative misuse; Obstet Gynecol Surv 2004; 59(2):128-140

4. Bechard de Spirlet M: Use of Misoprostrol in Gynaecology and obstetrics; Gynecol Obstet Fertil 2002; 30(4):317324

5. Radley DC, Finkelstein SN, Stafford RS:Off-label prescribing among office-based physicians. Arch Intern Med 2006;166:1021-1026. [Free Full Text]

6. Mühlbauer B, Janhsen K, Pichler J, Schoettler P: Off-label-Gebrauch von Arzneimitteln im Kindes- und Jugenalter. Dtsch Arztebl Int 2009; 106(3):25-31

7. BDI: Berufsverband Deutscher Internisten e.v.: Fragen und Antworten zum Thema off-Label-Use, aus dem Fragen-/Antwortenkatalog des Gemeinsamen Bundesausschusses (G-BA);

http://www.bdi.de/bdi/content/055/0601125.jsp

8. Keilholz U., Forum DKG 06/05: Off-Label-Use: Was können die Fachgesellschaften und die Deutsche Krebsgesellschaft tun? 35-8

9. Bundessozialgericht Urteil vom 19.03.2002, B1 KR 37/00 $\mathrm{R}$;

http://juris.bundessozialgericht.de/cgi-bin/rechtspre chung/document.py

10. Seidman AD, Formier MN, Esteva FJ, Tan L, Kaptain S, Bach A et al: Weekly trastuzumab and paclitaxel therapy for metastatic breast cancer with analysis of efficacy by HER2 immunophenotype and gene amplification; $j$ Clin Oncol 2001; 19:2587-2595

11. Dierks Ch.: Der Arzt und das Recht: Bundessozialgericht verfeinert Kriterien für Off-label use; Ärzte Zeitung; 09/ 2006

12. Schmitz St: Aktueller Stand der Expertengruppe „Off-label“", Forum DKG 06/05: 41-43

13. Weißbach L, Boedefeld EA: Off-label Verordnungen in der Onkologie; Bundesgesundheitsbl - Gesundheitsforsch - Gesundheitsschutz 2003; 46: 462-6

14. G-BA - Der Gemeinsame Bundesausschuss: Fragen und Antworten zum Off-Label-Use; http://www.g-ba.de/institution/sys/faq/78/

15. Dierks Ch: Der Arzt gerät in Beweisnot, Medical Tribune G\&M, Sonderausgabe Dezember 2007:16

16. Bruns J, Herz E: Off-Label-Use aus Sicht der Krankenkassen. Bundesgesundheitsbl Gesundheitsforsch Geunsheitsschutz 2003;46:477-482

17. Jacobs VR: Current status of financing and reimbursement of Trastuzumab (Herceptin $\left.{ }^{\circledR}\right)$ for adjuvant and advanced therapy of breast cancer in Germany; Breast Care 2006; 1:86-94

18. Schmitz St: Aus der Praxis: Die Therapieentscheidung muss beim Arzt bleiben; Im Focus Onkologie, Sonderausgabe 1/2006:12-13

19. KV (Kassenärztliche Vereinigung): Off-Label-Use: BSGUrteil stützt Ärzte in Zweifelsfällen;

http://www.kvberlin.de/40presse/50publikation/10bu $\mathrm{bu} / 2007$

20. OLG Köln, Urteil vom 30.05.1990 - 27 U 169/89

21. Schweim H, Behles C: Off-Label-Use oder von der Notwendigkeit der Arzneimittelzulassung; Bundesgesundheitsbl-Gesundheitsforsch-Gesundheitsschutz 2003; 46: 499-503

22. Hopf Ch, Philipowich G: Behandlung mit noch nicht zugelassenen Medikamenten: Zwischen Hoffen und Haften; Deutsches Ärzteblatt 2008, Jg 105(11) 
23. Guidance for industry: good reprint practices for the distribution of medical journal articles and medical or scientific reference publications on unapproved new uses of approved drugs and approved or cleared medical devices (draft guidelines). Rockville, MD: Food and Drug Administration, February, 2008.

24. Stafford RS,: Regulating off-label drug use - rethinking the role of FDA; NEJM 2008: 358(14):1427-9

25. Schirm E, Tobi H., de Jong-van den Berg LTW: Unlicensed and off label drug use by children in the community: cross sectional study. BMJ 324, 2002: 1312-3

26. Food and Drug Administration; U.S. Department of Health and Human Services, Center for Devices and and Radiological Health: Determination of intended use for 510(k) devices: Guidance for CDRH Staff (Update to K98-1), 2002: 2

27. FDA: Statement of William K. Hubbard Senior Associate Commissioner for Policy, Planning and Legislation Food and Drug Administration - Before the Subcommittee on Health Committee on Energy and Commerce House of Representatives, 2002:2
28. Jacobs VR, Thödtmann J, Brunner B, Kiechle M: Active cost management model for Gyneco-Oncological therapies to reduce pharmaceutical costs by $58.7 \%$ within one year; Geburtsh Frauenheilk 2005; 65:46-55

29. Ludwig WD: Erste Expertengruppe „Off-Label“: Was wurde erreicht? Forum DKG 06/05

30. Dierks C: Rechtliche Aspekte der Off-Label-Verordnung in der Praxis; Bundesgesundheitsbl - Gesundheitsforsch - Gesundheitsschutz 2003; 46: 458-461

Received: April 3, 2010 / Accepted: July 16, 2010

Address for correspondence:

Dr. Nina Ditsch

Department of Obstetrics and Gynaecology - Großhadern

Ludwig-Maximilians-University

Marchioninistr. 15

81377 Munich

Germany

Phone: +4989 7095-0; Fax: +49 89 7095-7573

E-mail: nina.ditsch@med.uni-muenchen.de 